\title{
Challenges of Teaching Mathematics to Students with Visual Impairment
}

\author{
M S Oyebanji \& Ubong Sam Idiong* \\ Department of Mathematics, Adeyemi College of Education, Ondo, Ondo State, Nigeria \\ *Corresponding author: idiongus@aceondo.edu.ng | Phone Number: +2348138029170
}

\section{ARTICLE HISTORY}

Received : 28 September 2020

Revised : 11 March 2021

Accepted : 10 April 2021

\section{KEYWORDS}

\section{Abacus;}

Braille Machine;

Stylus And Slates;

Taylor Frame;

\begin{abstract}
This study aimed at investigating the challenges of teaching mathematics to visual impaired students in school of the blind, a case study of some selected schools for the visually impaired. Questionnaire and interview were used for data collection from the respondents. The hypotheses in the study were tested using t-test with a-level of 0.05 through SPSS. The study followed a cross-section survey design and involved 80 respondents 20 for the visually impaired students, 10 for the Mathematics teachers, 10 special mathematics teachers, 40 low vision and non-visually impaired students. The findings revealed the visually impaired students receive bursaries from the government and non-government organization; meal, accommodation, and few scholastic materials from their school; extra time during mathematics classes and examination and friend support. However, constraining limitations in the method of instruction assessment used and the instructional materials provided were noted, on the basis of these findings, recommendation towards the better education of the visually impaired student studying mathematics should be encouraged and employment of special mathematics teachers.
\end{abstract}

This is an open access article under the CC-BY-SA license.

\section{INTRODUCTION}

The world today is powered by technology, fueled by information and driven by knowledge. Knowledge is the currency of modern life, and quality education for all is a necessity and not an option. Humans are gifted with five senses: vision, hearing, touch, taste and smell. As far as educational setting is concerned, most of the curriculum presumes that the student has perfect eyesight as an important feature to take full advantage of educational opportunities. Persons with visual impairment (VI) are found virtually in all societies of the world. There are an estimated 19 million blind children worldwide (WHO, 2012). Approximately one child goes blind every minute in the world, making a total of 500,000 children who go blind each year in the world. In the US alone, the number of school children who are blind is estimated to be more than 485,500 (NFB, 2012). All these students are essentially print-disabled (i.e., a person who cannot effectively read print because of a visual, physical, perceptual, developmental, cognitive, or learning disability) or progressively would become print-disable. Innovations in the field of educational technology such as "Audio Math" (Sanchez \& Flores, 2005), tactile graphics (images those use raised surfaces so that VI individuals can feel them) are opening new avenues for the VI individuals. Though then picture appears to be quite rosy, inaccessibility of learning materials (Sahyun et al., 1998), and increasing focus on visual curriculum, poses paramount challenge to the information revolution. Therefore, it is imperative to understand and appreciate the challenges faced by VI students in academic - setting and various strategies utilized by them to mitigate the challenges.Every learner should have educational opportunities consistent with his/her abilities NERDC (Nigerian Educational Research and Development Council,1989). Egbo (2005) noted that despite many well-intentioned educational policies that have been adopted by the Federal Government of Nigeria (FGN), Education in Nigeria has fallen victim to the nation's chronic, social, and political challenges that tend to reduce institutional efficiency. Abang (1992) noted that the implementation of the 6-3-3-4 shown education system in Nigeria has not been successful in the schools for learners with disabilities because the FGN has no requisite commitment and seriousness in the implementation of the system.

Vision enables important access to information that supports students' development of mathematical concepts and procedures (Emerson \& Anderson, 2018; Hershkowitz, Markovits, Rosenfeld, Ilani, \& Eylon, 2018). Many basic mathematical concepts take the form of words that describe visual phenomena (Jones, 2018). Accordingly, their awareness or understanding of spatial concepts and directional concepts are more challenging to grasp compared with children without VI (Hatwell, 2003). Consequently, it is natural that many children with VI are offered fewer experiences of how mathematical concepts are used in daily-life communication than are sighted children (Bateman et al., 2018; Emerson \& Anderson, 2018). In the field of visual impairment, researchers have traditionally studied students with VI as one group of 
students, despite the fact that visual impairment can be caused by a variety of conditions (Warren, 1994,). Experience of instructors of the VI are similar to the results reported by Rapp and Rapp (1992), namely that students who use Braille are less likely to participate in advanced mathematics classes.

In addition, as a population, students with VI tend to perform below their ability in mathematics compared with in other academic subjects (Beal \& Shaw, 2008; Freeland, Emerson, Curtis, \& Fogarty, 2010) One factor that may limit the participation of blind and partially sighted learners in mathematics education may be what Emerson and Anderson (2018) call the trend toward more visually based mathematics materials. Many mathematics textbooks have visual images with important content information that is not transcribed or described in either Braille books or digital versions of the texts. This trend is making textbooks, which to some extent are already inaccessible to students with VI, even more challenging for blind and partially sighted learners.

Graphs, charts, diagrams, figures, and drawings are used as mathematical tools to communicate huge amount of data or relationships between variables in a simplified and concise way (Akar \& Övez, 2018). An important mathematical skill is to gather information from such graphics and use it to solve problems (Rosenblum, Cheng, \& Beal, 2018). However, curricular graphic materials are visual in nature and therefore many students with VI face considerable challenges in reading them (Rosenblum \& Herzberg, 2015). The provision of suitable learning materials is vital in mathematics education. The abacus is a tool for addition, subtraction, multiplication, and division by students with VI, in a similar way to how pencil and paper are used for calculations by sighted students. Often, it is up to the teacher to decide whether the student should learn how to use an abacus. This may be a difficult decision because the effectiveness of the abacus has been questioned (Ferrell, 2011).

Technology can offer new opportunities and valuable access to information for students with VI by complementing the use of tactile devices, Braille, and large print with audio (Beal \& Rosenblum, 2018; Pitchford, Kamchedzera, Hubber, \& Chigeda, 2018; Supalo, Hill, \& Larrick, 2014; Supalo, Isaacson, \& Lombardi, 2013). Digitally enhanced learning tools may thus transform educational environments by making the learning process more encompassing, more engaging, and more collaborative (Bin Tuwaym \& Berry, 2018 ; Metatla et al., 2018 ).

Self-esteem may play a profound role in all aspects of a child's development (Breckler, Olson, \& Wiggins, 2006; Brooks, 1992). A student's self-esteem may be dependent upon his or her psychological adjustment, quality of life, adaptive behaviour, relationships with friends, motivation, school performance, and success in life (Augestad, 2017b; Brooks, 1992; Papadopoulos, Metsiou, \& Agaliotis, 2011; Saigal, Lambert, Russ, \& Hoult, 2002). In STEM self- confidence is one factor that contributes to a student's motivation to learn mathematics. Supalo et al. (2013, p.196) state that "inadequate hands-on science experiences may inhibit development of self-confidence concerning one's capacity to independently function in scientific endeavors, and that low self-confidence in the sciences may be associated with consideration of nonscientific college studies rather than studies in the sciences'.

In a literature review published in 2013, the author focused on STEM education (science, technology, engineering, and mathematics education) (Cryer, 2013), but we were unable to identify the results that focus only on mathematics education. We found it relevant to conduct a systematic review and to evaluate the quality of the research and the effect of any intervention, with the aim of summarizing the evidence-based academic knowledge about mathematics education among students with VI.

Visual impairment has been viewed by various people based on their perceptions, disciplines and the effects it imposes on them. Millais (2010) saw it as the condition of lack or reduction in visual perception due to physiological or neurological factors. Eniola (2008) categorized persons with visual impairments as those with total blindness, those with low vision and those who are partially sighted. However, the term Visual Impairment" is now generally accepted as referring to people within the visual range of no sight at all to useful but defective vision, rather than the more strictly categorical terms of "blind", "low vision" or "partially sighted" (Nkangwung, 2010).

Total blindness is the inability to discriminate light from dark, or the total inability to see. Total blindness is otherwise known as legal blindness, and has visual acuity of 20/200 or less in the better eye after the best possible correction with glasses (Heward, 2004). Low vision is a severe visual impairment with minimal visual function after correction. It can be increased through the use of optical aids and environmental modifications (Corn \& Ryser, 1989). Students with low vision learn from vision and other sense. Functional vision will depend on factors such as lighting, size of print or objects, and distance. Low vision is characterised by visual acuity of $20 / 200$ to $70 / 200$ (Snellen) or6/18 to $6 / 60$ in the better eye after the best possible correction or a field of vision between 20 to 30 degrees (WHO, 1992).

Some common causes of VI in children after birth include: hormonal imbalance, infectious diseases such as smallpox, chicken pox, scarlet fever, trachoma, epilepsy, onchocerciasis (river blindness), measles, cataract, glaucoma, strabismus, retinitis pigmentosa among others (Olukotun, 2003). Accident and injuries involving the organs of sight can also results in visual impairment. Apart from diseases, physiological and pathological causes, the Nigerian traditional culture believes in different causes of visual impairment, for instance, havoc from evil spirit and witches, prolonged gaze at nakedness of an opposite sex, punishment for past sins committed by parents, anger of the gods and the violation of traditional norms (Ajobiewe et. al, 2004). Traditional or cultural causes of blindness according to Osinugaet.al. have no scientific proof.

The Christian missionaries to Africa contributed positively to the teaching of the visually impaired by establishing the first school for the blind Gindiri by Sudan Interor Mission in 1953. Also, in 1962, Pacelli School for the Blind was established by the Catholic Mission under Archbishop Taylor. This led to the birth of many special schools for the blind.

Zindif (1997) opines that complete involvement in the education of the disabled by FGN did not take place until the 1970s when the then Head of States, Major General Yakubu Gowon declared government's interest in the education of the disabled. He directed that all the state Ministries of Education must establish units for special education so as to strengthen the existing schools. Nigeria's President Muhammadu Buhari signed into law the Discrimination Against Persons with Disabilities (Prohibition) Act, 2018, following 9 years of relentless advocacy by disability rights groups and activists.

According to the World Health Organization's 2011 World Disability Report, about $15 \%$ of Nigeria's population, or at least 25 million people, have a disability. Many of them face a number of human rights abuses including stigmatisation, discrimination, violence, and lack of access to healthcare, 
housing, and education. Today, elements of special education are being taught in our colleges of education and some universities' faculty of education to salvage the situation.

Schools with dormitories or regular day schools with special assistance may be an appropriate educational approach for individual students with VI or other disabilities. (Scholl, 1986). The Nemeth Code for Braille Mathematics and Science is the current standard for tactile mathematics textbooks and allows students who are blind to braille all the necessary mathematical symbols up to and including the highest levels of mathematics (Kapperman,1994;Wittenstein,1993). Auditory representations of advanced mathematical concepts cannot truly convey the essential and precise information required in mathematics (Cullers, 2003 Keynote address, American Printing House for the Blind).

Some authors have proffered possible solution to the structural problem of helping the VI students. Ekwueme (2003) also discussed problems of equipment, teacher training facilities, funding, law and administrative rigidity as key problems inhibiting the steady growth of special education in Nigeria. It is obvious that the locations of many tertiary institutions of learning in Nigeria are not freely accessible to the visually impaired with hindrances varying from complex storey buildings with coiled stair cases, uncovered gullies, bad lavatory and rough environment which prevent free movement of the visually impaired within the school. In line with this, Milaham (1993) says the visually handicapped persons encounter numerous barriers and hazards ranging from psycho-social, emotional to physical environment which hinder their successful movement. Hergart and Pocklington (1982) have also established that even in educational institutions where visually impaired persons being educated along with their normal peers (with the objectives of fostering positive attitudes and more acceptance of the VI persons among others), negative attitudes have continued to be expressed towards the visually impaired students by the teachers and normal students. Ntukiden et al. (2005) asserted that facilities are grossly inadequate. Philip and Todd (1999) have pointed out that another global controversy of the present era is funding. Higher education is an expensive undertaking and there is much debate concerning how to fund expanding academic systems.

\section{Research Hypotheses}

$\mathrm{HO}_{1}$ : Availability of special teachers has no effect on teaching of mathematics for visually impaired.

$\mathrm{HO}_{2}$ : Government policies have no effect on the teaching of blind student in inclusion school

$\mathrm{HO}_{3}$ : There is no relationship between students' interest and the teaching of mathematics to the visually impaired.

$\mathrm{HO}_{4}$ : Availability learning materials has no effect on teaching the visually impaired mathematics.

$\mathrm{HO}_{5}$ : Teaching aids in inclusive school have no effect on teaching the visually impaired mathematics.

\section{METHODS}

The study work was designed to investigate the challenges facing mathematics in school of the blind using the school of the blind Owo as a case study, Owo local government area, Ondo state. Verbal interview: Unstructured types of interview were adopted to obtain some valuable information from teachers. The respondents view and feelings about the challenges facing in mathematics education. Questionnaires were administrated to eighty participants and were collected on the spot; the verbal interviews were also included in the process of collecting data from the visually impaired through personal visit to the schools. The school assistant Headmaster was used as cooperating assistant. The teacher responded well to the questionnaires. Each student was allowed to fill respond conveniently. Hence the researcher collected and recorded them for analysis. The researcher also transcribes the audio interview (verbal interview) in written form.

\section{RESULTS AND DISCUSSION}

\subsection{Results}

Availability of special teachers versus Mathematics teaching

Research Hypothesis $\left(\mathbf{H O}_{1}\right)$ : Availability of special teachers not affects mathematics teaching.

Table 1. Showed the opinion of the respondents on Availability of special teacher on Mathematics teaching.

\begin{tabular}{|c|c|c|c|c|c|c|c|}
\hline Variables & $\mathrm{N}$ & $\mathrm{X}$ & S.D & $\mathrm{t}$-cal & $\mathrm{t}$-cri & Df & Decision \\
\hline $\begin{array}{l}\text { Availability of } \\
\text { special } \\
\text { teachers }\end{array}$ & 40 & 9.6 & 4.38 & 3.980 & 2.045 & 29 & $\begin{array}{c}\text { Rejected } \\
\mathrm{HO}_{1}\end{array}$ \\
\hline $\begin{array}{l}\text { Math } \\
\text { Teaching }\end{array}$ & 40 & 7.20 & 3.38 & & & & \\
\hline
\end{tabular}

The table 1. showed that the t-calculated (tc) was 1.589 while the t-tabulated ( $\mathrm{tt}$ ) was 2.045 at 0.05 level of significance (a), degree of freedom $=29$. Since the calculated t-value of 3.980 is greater than the critical table value of 2.045 i.e $3.980>2.045$. Therefore, the null hypothesis which states that availability of special teacher does not affect mathematics teaching is rejected.

\section{Government policies versus Mathematics Teaching}

Research Hypothesis $\left(\mathbf{H O}_{2}\right)$ : Government policies have no effect on the teaching of blind students in inclusion school.

Table 2. Showed the opinion of the respondents on influence of government policies in special education on teaching of Mathematics.

\begin{tabular}{lccccccc}
\hline \multicolumn{1}{c}{ Variables } & $\mathrm{N}$ & $\mathrm{X}$ & $\mathrm{S} . \mathrm{D}$ & $\mathrm{t}-\mathrm{cal}$ & $\mathrm{t}$-cri & Df & Decision \\
\hline $\begin{array}{l}\text { Government } \\
\text { policies }\end{array}$ & 40 & 6.60 & 5.08 & 4.589 & 2.045 & 29 & $\begin{array}{c}\text { Rejected } \\
\mathrm{HO}_{2}\end{array}$ \\
\cline { 1 - 3 } & 40 & 11.40 & 4.77 & & & & \\
$\begin{array}{l}\text { Meaching } \\
\text { Teach }\end{array}$ & & & & & & & \\
\hline
\end{tabular}

The table 2 showed that t-calculated (tc) was 3.980 while the $\mathrm{t}$-tabulated (tt) was 2.045 at 0.05 level of significance (a), degree of freedom $=29$. Since the calculated $t$-value of 4.589 is greater than the critical table value of 2.045 i.e. $4.589>2.045$. Therefore, the null hypothesis which states that there is no influence of teacher's qualification in sign language on teaching of mathematics is rejected.

Availability of learning materials versus mathematics teaching in special schools 
Research Hypothesis $\left(\mathbf{H O}_{3}\right)$ : Availability learning materials has no effect on teaching the visually impaired mathematics.

Table 3. Showed the opinion of the respondents on the Availability of learning materials on Mathematics teaching in special schools

\begin{tabular}{|c|c|c|c|c|c|c|c|}
\hline Variables & $\mathrm{N}$ & 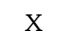 & S.D & $\mathrm{t}$-cal & t-cri & Df & Decision \\
\hline $\begin{array}{l}\text { Availability of } \\
\text { special } \\
\text { teachers }\end{array}$ & 40 & 9.6 & 3.980 & 3.980 & 2.045 & 29 & $\begin{array}{c}\text { Rejected } \\
\mathrm{HO}_{3}\end{array}$ \\
\hline $\begin{array}{l}\text { Math } \\
\text { Teaching }\end{array}$ & 40 & 7.20 & 3.38 & & & & \\
\hline
\end{tabular}

The t-calculated (tc) was 1.589 while the t-tabulated $(\mathrm{tt})$ was 2.045 at 0.05 level of significance (a), degree of freedom $=9$. Since the calculated t-value of 3.980 is greater than the critical table value of 2.045 i.e $3.980>2.045$. Therefore, the null hypothesis which states that availability of special teacher does not affect mathematics teaching is rejected.

\section{Students' interest versus Mathematics teaching in special schools}

Research Hypothesis $\left(\mathrm{HO}_{4}\right)$ : there is no relationship between students' interest and the teaching of mathematics to the visually impaired.

Table 4. Showed the opinion of the respondent on the influence of teaching method on Mathematics teaching.

\begin{tabular}{|c|c|c|c|c|c|c|c|}
\hline Variables & $\mathrm{N}$ & $\mathrm{X}$ & S.D & t-cal & $\mathrm{t}$-cri & Df & Decision \\
\hline $\begin{array}{l}\text { Availability } \\
\text { of special } \\
\text { teachers }\end{array}$ & 40 & 21.60 & 7.162 & 2.060 & 2.045 & 29 & $\begin{array}{c}\text { Rejected } \\
\mathrm{HO}_{4}\end{array}$ \\
\hline $\begin{array}{l}\text { Math } \\
\text { Teaching }\end{array}$ & 40 & 8.40 & 8.40 & & & & \\
\hline
\end{tabular}

The t-calculated (tc) was 2.060 while the t-tabulated $(\mathrm{tt})$ was 2.045 at 0.05 level of significance (a), degree of freedom $=29$. Since the calculated t-value of 2.060 is greater than the critical table value of 2.045 i.e. $2.060>2.045$. Therefore, the null hypothesis which states that teacher teaching method does not have influence on mathematics teaching is rejected.

\subsection{Discussion}

The teaching process involved by visually impaired and non-visually impaired teachers have effect on the learners' achievement. However these students face number of challenges that other students do not face. In hypothesis one, it is observed the Availability of teachers does not affect mathematics teaching. This result contract (Aila, 2011) findings who stated that visual impairment is a factor that may rise up learning problems and children with visual difficulties may develop learning problems especially in Mathematics. There is need for employment of special teachers into the working force to foster individualized teaching and learning process.

It is obtained from the second hypothesis that, there is influence of teacher's qualification in special education on teaching of mathematics which was in line to Chikukwa \& Chimbwanda (2014) findings who argues that there is a casual link between the quality of teaching and level of students' outcome, meaning any approach that increases the quality of teachers should consequently improve students' outcome. It is noted that special education restricted their staff to trained special education. Even mathematics teachers in inclusive school only teach learners together in group rather than individualized teaching.

Results from hypothesis three also shows that Teacher teaching method have influence on mathematics teaching which agrees with Owino (2011) whose research indicated that students who learn mathematics by problem solving and discovery learning methods are more active in comparison with the students under the traditional teacher-centered methods.

\section{CONCLUSION}

The achievement of a well-designed curriculum in special education depends on the ability of the school administrator to ensure appropriate educational opportunities for students with disabilities. This involves adequate planning of the curriculum that focuses on activity-based learning, self-directed learning, and cooperative group work and peer learning. The school administrator need to make provision for adequate resources for the implementation of effective curriculum which involves provision of adequate personnel for the training and re-training of in-service and pre-service teachers who will be able to develop key skills within a broad content areas, using individualized education programme, variety of assessment tools as well as multi-disciplinary approaches in the education of students with special needs. The school administrator needs to provide teacher-educators with facilities that will enable them to possess the skills needed, understand the curriculum, new methods, and techniques in teaching for the attainment of the goals and objectives of special education.

Designing an appropriate curriculum for special education in an urban school can be a very interesting and exciting experience where the following principles are taken into consideration in planning curriculum for them:

1. Limit the number of new concepts introduced in a lesson to avoid confusing the students;

2. Teach from simple to complex and from concrete to abstract. Be sure that students understand one concept before going to another;

3. Do not use elaborate language or unclear models in teaching concepts. Use simple language;

4. Space your introduction of new concepts. Do not introduce many concepts at a time to students. It can be confusing. Provide sufficient guided practice for the group before progressing to individual turns;

5. Introduce higher-order skills only when the basic concepts have been learnt by students. Higher-order skills will not be useful or reliable if the basic concepts are not firm;

\section{ACKNOWLEDGEMENTS}

I wish to acknowledge the local education authorities who gave us listening hears and cooperation in data gathering in this research.

\section{REFERENCES}

Abang T. B. (2005). Exceptional Child. Handbook of Special Education, Jos Fab Educational Books.

Abang, T. B. (1992). Special education in Nigeria. International Journal of Disability, 29(1), 13-18. 
Adebiyi, B. A. (2004). Special Education (A Historical Survey). Footprints Journal of COEASU.

Adebiyi, B. A. (2007). Visually-Impaired Education: Yesterday, Today and Tomorrow. Essays in Education Volume 22, Fall 2007.

Ajobiewe, Theo, Adebiyi, B.A., \& Osinuga, M.A. (2004). Visual Impairment. In J.M. Okuoyibo (Eds.). An Introduction to the Education of Children with Special Needs. (Revised Edition). Ibadan: Emola-Jay Com. Pg. 108-119.

Ajaja, A. A. (2006). Self Employment of Persons with Disabilities. In: B. A. Adebiyi. (Ed.). Employment of Persons with Disability. A Publication of National Resource Centre for the Disabled.

Andre James M. (2000). Curriculum Development for the Year 2000: A case Study of the Process of Curriculum Revision in a Professional school. Dissertation Abstracts International, 1991, 3612-A.

Burrello, L. C., \& Lashley, C. (1992). On organizing the future: The destiny of special education. In K.Waldron, A.Riester, \& J. Moore (Eds.), Special education: The challenge for the future (pp. 64-65). San Francisco: Edwin Mellen Press.

Chantal J. Gervedink Nijhuis, Jules M. Pieters and Joke M.Voogt. (2013). Influence of culture on curriculum development in Ghana: an undervalued factor. Journal of Curriculum Studies, 2013. DOI: $10.1080 / 00220272.2012 .737861$.

Egbo, B. (2005). The state and future of education in sub-Saharan Africa: Lesson learned from developed countries. A keynote address presented at the 2005 National Conference of the Nigerian Primary and Teacher Education Association, Asaba Delta State, June 14, 2005.

Eni-Olorunda, T. J. (2001). Community-Based Rehabilitation (CBR) and Mentally- Retarded Child: Challenges of the Present Political Dispensation in Nigeria. In: J.A. Ademokoya (Ed.).Exceptional Nigerians in the New Political Dispensation. Ibadan: Options Books.

Eskay, M. (2001). Cultural perceptions of special education administrators in small scale societies (Doctoral dissertation, Loyola University).

Eskay, M. (2009). Cultural perceptions of special education administrators in Nigeria. LAP Lambert Academic Publishing AG \& Co KG, Koln, Germany FRN (Federal Republic of Nigeria). (2004). National policy on education, NERDC (4th ed.). Abuja: NERDC Press. FRN (Federal Republic of Nigeria). (2007). Education Reform Act 2007. The National Assembly of the Federal Republic of Nigeria, Abuja.

Heward, L. W. (2004). Exceptional Children: An Introduction to Special Education. (7th ed.). Ohio: Merrill Prentice hall.

Heward, L. W. (2004). Exceptional Children: An Introduction to Special Education.(7th ed.). Ohio: Merrill Prentice hall.

http://en.wikipedia.org/wiki/Curriculum.implimentation

http://www.tki.org.nz/r/health/curric_devt/lit_review/pe/litr ev_pe7_e.php

Kyari, F. et al. (2009). Prevalence of Blindness and Visual Impairment in Nigeria: The National Blindness and Visual Impairment Survey Investigative Opthalmology\& Visual Science, 5 (5).

Mogbo, I. N. (2002). Restructuring the curriculum of the disabled for self-sustenance, counseling implications. The Journal of National Council for Exceptional Children, 6(4), 76-80.
NERDC (Nigerian Education Research and Development Council). (1989). Handbook on education and care of the exceptional child. Lagos: NERDC Press.

Nwachukwu, R. C. (2006). Curriculum planning for special needs children: Contemporary issues in special needs education. Journal of the National Council for Exceptional Children, 7(1), 276-280.

Obani, T. C. (2003). Empowerment of People with Special Educator's Perspective.A Publication of the School of Vocational and Technical Education, Federal College of Education (Special), Oyo.

Obani, T. O. (2004). Handicap, Disability and Special Education. What Parents and Teachers Want to Know.

Obani,T. O. (2004). Handicap, Disability and Special Education. What Parents and Teachers Want to Know.

Oboegbulem, A. I. (2002). The re-training needs of teachers for the universal basic education. In Ali, \& Okeke (2002) (Eds.), Philosophy and education (pp. 100-111).

Onitsha, Nigeria: Africana-Fep. Publishers Ltd..Oboegbulem, A. I. (2004). Administrative strategies for the preparation of teachers of special needs children: The exceptional child. The Journal of the National Council for Exceptional Children, 7(1), 319-326.

Olukotun, J. O. (2003). Teaching Children with Blindness and Visual Impairment: A Basic Text. Ibadan: Codat publications.

Olukotun, J. O. (2003). Teaching Children with Blindness and Visual Impairment: A Basic Text. Ibadan: Codat publications.

Olukotun, J. O. (2003). Teaching Children with Blindness and Visual Impairment. A Basic Text. Ibadan: Codat Publications

Onwubolu, C. O. (2005). The state and future of special education in Delta state. Paper presented at The Nigerian Primary and Teacher Education Association Conference, FCE (Technical) Asaba, June 13-17, 2005.

Ozoji, E. D. (2003). Special education for beginner professionals. Jos: Deka Publications.

Ozoji, E. D. (2005). Re-positioning special needs education for effective service delivery in Nigeria (Deka Special Education Monograph Series No. 8). Jos: Deka Publication.

Rea, P. J., Mclaughlin, V. L., \& Walther-Thomas, C. S. (2002). A comparison of outcomes for middle school students with learning disabilities in inclusive and pullout programs. Exceptional Children, 68, 203-222.

Sánchez, J., Flores, H. (2005). Training Blind Children to Develop Mathematics Skills Through Audio. Proceedings of the Cybertherapy 2005, Basel, Switzerland, June 6-10, 2005, pp.123-124.

Sage, D., \&Burrello, L. (1994). Leadership in educational reform: An administrator's guide to changes in special education. Baltimore: Brookes.

Scholl, G. (Ed.) (1986). Foundations of Education for Blind and Visually Handicapped Children and Youth. American Printing House for the Blind. Louisville, KY 40206.

Taba, H. (1962). Curriculum development: Theory and practice. New York: Harcourt Brace and World.

The Free Dictionary (2011).Definition of Visual Impairment. Retrieved from :

http:// thefreedictionary.com/Visual+Impairment">Visual Impairm 
Tichafa J. (2000). Chikumbu, Curriculum theory, design andassessment, Ministry of Education, Sport and Culture Masvingo, Zimbabwe. The Commonwealth of Learning, 2000.

Turnbull, H. R., \& Cilley, M. (1999). Explanations and implications of the 1997 amendments to IDEA. Upper Saddle River, N. T.: Merril/Prentice Hall.

UNESCO. (2000). Module 2 counseling regional training seminar on guidance and counseling. Zambia: UNESCO Press.

USDOF. (2002). No child left behind: ESEA reform. Retrieved October 8, 2000, from: http://www.Nochildleftbehind.gov/next/ overview/index.html

Zindif (1997).Special Education in Africa. Botswana: Tasalls Publishing. 